\title{
RESTING ENERGY EXPENDITURE IN SKILLED ATHLETES
}

Introduction. Resting energy expenditure is an important indicator of metabolic status. The impact of long-term sports activities on resting energy expenditure is not definitively determined. Published results on REE in athletes have significant differences.

Purpose. To examine the resting energy expenditure in skilled athletes and compare it to that of untrained people

Methods. Analysis and generalization of scientific data in the field of research, bioelectrical impedance analysis, indirect calorimetry and statistical data processing.

Results. Resting energy expenditure (REE) in male athletes was $2132.9 \pm 339.7 \mathrm{kcal} \cdot$ day $^{-1}$. REE is most correlated with body weight $(r=0.77, p<0.05)$ and lean body mass (LBM) $(r=0.74$, $p<0.05))$. Analysis of scientific data shows that REE in athletes is not constant and may decrease after a period of intense training. These changes are associated with a decrease in the rate of metabolic reactions and a probable increase in catabolic processes. During intense training, the need for energy increases significantly, and in case of insufficient compensation of energy expenditure from diet, a cascade of metabolic, hormonal and nervous reactions aimed at maintaining homeostasis and energy conservation is provoked.

Originality. Resting energy expenditure and body composition relation was analyzed in skilled athletes and non-athletes.

Conclusion. Resting energy expenditure in male athletes is significantly higher $(p<0.05)$ compared to untrained men $\left(2132.9 \pm 339.7\right.$ and $1772.1 \pm 305.7 \mathrm{kcal} \cdot$ day ${ }^{-1}{ }^{1}$ respectively). This increase is associated with both an increase in LBM and an increase in its metabolic activity. Among the factors influencing the REE of athletes, the greatest contribution is made by body weight $(r=0.77, p<0.05)$ and lean body mass $(r=0.74, p<0.05)$, as well as the intensity of physiological processes. Proactive monitoring of energy consumption and expenditure during intense training periods to compensate for increased energy expenditure can provide more objective control of the athlete's recovery. Therefore, the determination of resting energy expenditure is an informative indicator of metabolic status and can be used in comprehensive monitoring of functional status and recovery of the athlete. body mass.

Key words: athletes; metabolism; resting energy expenditure; body composition; lean

Formulation of the problem. Analysis of recent research and publications.

Basal metabolic rate (BMR) is the minimum amount of energy needed to ensure a person's life functions while at rest (respiration, hematopoiesis, excretory functions, maintaining muscle tone, nervous and endocrine system activity, etc.). In the average person, $60-80 \%$ of total energy expenditure (TEE) is accounted for by BMR. It should be noted that although the term "basal metabolic rate" is commonly used in the modern scientific literature, there is a certain specificity of its use. Determination of basal metabolic rate (BMR) involves the following conditions: the study is performed at rest, in the morning, with the subject lying on one's back, immediately after waking up, on an empty stomach and at intervals of 12-14 intervals after the last meal, indoors, at a temperature of $20^{\circ} \mathrm{C}$. These requirements significantly complicate the study and significantly limit its feasibility. If these conditions are not fully met, it is a matter of resting energy expenditure (REE) or resting metabolic rate 
(RMR). The difference between the basic metabolism and resting energy expenditure is small, about $10 \%[1,2]$.

With increasing physical activity, the percentage of REE in the overall distribution of TEE decreases. According to studies by J.L.Thompson (1996) and B.A. Biedleman (1995), in skilled male athletes REE is $38-47 \%$ of TEE, and in women it accounts for about $42 \%$. During days of repetitive, heavy competition, such as ultramarathons, REE can be less than $20 \%$ of TEE. (G.P. Rontoyannis et al. 1989).

It should be noted that a significant amount of BMR energy is spent on anabolic processes. There is a direct relationship between basal metabolism and the rate of protein recovery. Significant energy is required by such processes as, amino acids transport, processes of regulation and integration of protein metabolism and nitrogen metabolism. About $4 \mathrm{kcal}$ of energy is spent on $1 \mathrm{~g}$ of protein biosynthesis. [1].

If there is insufficient dietary energy intake, REE can be reduced by $20 \%$ compared to normal values. This is a manifestation of protective functions aimed at conserving energy in the event of its long-term deficit $[1,2,3,4]$. ].

A number of researchers note a possible decrease in REE in athletes after a period of intense training $[5,6,7]$. This is due to a decrease in the rate of metabolic reactions and a possible increase in catabolic processes.

Thus, resting energy expenditure is an important indicator of metabolic status, a decrease in which indicates a decrease in the rate of metabolic processes at rest, and may also indicate a decrease in the intensity of anabolic processes.

The impact of long-term sports activities on resting energy expenditure is not definitively determined. Published results on REE in athletes have significant differences. Thus, the studies of Ravussin and Bogardus (1989), Almeras et al (1991), Taguchi et al (2001), Koshimizu et al. (2012) found higher REE values in endurance athletes compared to untrained people. At the same time, the studies of Tremblay et al (1983), Schultz et al (1991), and Herring et al (1992) did not reveal significant probable differences in the REE values [12].

Therefore, it is of scientific interest to study the resting energy expenditure in athletes. REE data can be used to study the metabolic status of athletes of different specializations, its relationship to special performance and possible ways to correct it in order to maintain performance and improve recovery processes.

\section{Connection with scientific programs or practical tasks}

The research was carried out within the scientific topics of "Improvement of the functionality assessment system in qualified athletes" (GR № 0120U102907) and "Control and correction of qualified athletes' metabolism under conditions of intense physical effort" (GR № 0120U103004).

The purpose of the study is to examine the resting energy expenditure of qualified athletes and compare it to that of untrained people.

\section{Research methods and organization}

Analysis and generalization of scientific data in the field of research, bioelectrical impedance analysis (Tanita BC-545, Japan), indirect calorimetry (Fitmate, Cosmed, Italy), statistical data processing (Statistica 12, USA).

The research was conducted in accordance with the basic bioethical norms of the Helsinki Declaration of the World Medical Association on Ethical Principles of Scientific and Medical Research, as amended (2000, as amended in 2008), the Universal Declaration on Bioethics and Human Rights (1997), and the Council of Europe Convention on Human Rights and Biomedicine. 1997). Each study participant provided written informed consent to 
participate in the study. 101 examinations of body composition and resting energy expenditure in 76 male athletes of cyclic sports related to endurance (biathlon, rowing, canoeing, rowing slalom, modern pentathlon) and martial arts ( boxing, taekwondo) were conducted.

The studies were performed in the morning on an empty stomach, before training. After measuring body composition, energy expenditure was measured in the supine position for 15 minutes. The following indicators were determined:

-anthropometric data - length and body weight.

-body composition - weight and percentage of adipose tissue, lean body mass.

- resting energy expenditure (REE) per day $\left(\mathrm{kcal} \cdot\right.$ day $\left.^{-1}\right)$. Determined on the basis of data on oxygen consumption at rest.

-resting energy expenditure per $\mathrm{kg}$ of body weight $\left(\mathrm{kcal} \cdot \mathrm{kg}^{-1} \cdot \mathrm{day}^{-1}\right)-$ was calculated mathematically on the basis of daily REE and body weight.

-resting energy expenditure per $\mathrm{kg} \mathrm{LBM}\left(\mathrm{kcal} \cdot \mathrm{kg} \mathrm{LBM}^{-1} \cdot\right.$ day $\left.^{-1}\right)$ - was calculated mathematically on the basis of daily REE and lean body mass.

- adjusted resting energy expenditure per $\mathrm{kg}$ of LBM $\left(\mathrm{kcal} \cdot \mathrm{kg} \mathrm{LBM}{ }^{-1} \cdot\right.$ day $\left.^{-1}\right)$. Determined mathematically on the basis of data on energy expenditure of adipose tissue [3], daily REE and LBM. The energy consumption of adipose tissue was deducted from the daily $\mathrm{REE}$ at the rate of $4.5 \mathrm{kcal}$ per $\mathrm{kg}$ of adipose tissue [3]. The obtained data were divided by LBM in $\mathrm{kg}$.

The obtained data were analyzed using the methods of mathematical statistics.

\section{Research results and their discussion}

The basic metabolic rate and resting energy expenditure are characterized by individual features. Their performance is influenced by many factors:

- body size. Basal metabolic rate depends first of all on body weight. An increase in body weight by $10 \mathrm{~kg}$ is accompanied by an increase in energy expenditure by an average of $120 \mathrm{kcal}[1]$;

- body composition. Internal organs and muscle mass are the most metabolically active tissues in the body, so people with more lean body mass have a higher BMR compared to people with the same body weight, but a lower percentage of LBM;

- age. Energy consumption is highest in children and adolescents, due to the growth process, which requires significant energy expenditure. Thus, for children and adolescents, BMR per $1 \mathrm{~kg}$ of body weight is higher than adults. The energy expenditure associated with weight gain is $5 \mathrm{kcal}$ per kg of body weight. In adults, BM usually remains fairly constant, but after the age of 40 it decreases by about 2-3\% annually, which is associated with a decrease in LBM $[1,3]$;

- sex. Given the same length and body weight, men have an average of 5-10\% higher BMR, which, above all, explain the greater LBM [1, 3, 13].

- hormonal status. Thyroid and adrenal hormones have the greatest effect on basal metabolism. With hypothyroidism, it can decrease by $30 \%$, and with thyrotoxicosis - it can increase by $50-70 \%$. Increased adrenaline secretion during emotional stress causes a temporary increase in BMR. In women, BMR is affected by the phase of the menstrual cycle the minimum values of BMR are observed in the follicular phase (beginning of the cycle), the maximum - in the luteal phase (at the end of the cycle). The difference between these two phases reaches 100-300 kcal/ day [1, 2];

- body temperature. Body temperature affects biochemical reactions: its increase by 1

${ }^{\circ} \mathrm{C}$ is accompanied by an increase in BMR by $13-15 \%$;

- environmental temperature. The minimum values of BMR are observed at a temperature of $26^{\circ} \mathrm{C}$. An increase or decrease in ambient temperature leads to an increase in the intensity of metabolic processes [1]; 
- genetic factors. Studies by Bouchard et al. (1989) and Ravussin (1989) demonstrated the significant role of heredity for BMR. Family ties are associated with $11 \%$ variability in basal metabolism, and in twins and parent-child pairs, heritability explained for $40 \%$ of its variability;

- food status. In the case of a long-term deficit of dietary energy intake, the BMR can be reduced by $20 \%$ compared to normal values. This is a manifestation of protective functions aimed at conserving energy in the event of its long-term deficit $[1,2,3]$;

The results of the study of resting energy expenditure and body composition in male athletes are presented in table 1 .

Anthropometric characteristics, body composition and REE of athletes

Table 1 and untrained men (according to Heymsfield et al. (2002)

\begin{tabular}{|c|c|c|c|c|}
\hline \multicolumn{2}{|c|}{ Indicator } & $\begin{array}{l}\text { Athletes } \\
(\mathrm{n}=101)\end{array}$ & $\begin{array}{l}\text { Untrained } \\
(\mathrm{n}=130)\end{array}$ & $\begin{array}{c}\text { The } \\
\text { difference, } \\
\%\end{array}$ \\
\hline \multicolumn{2}{|l|}{ Height, $\mathrm{cm}$} & $181,5 \pm 8,5$ & $177,4 \pm 21,5$ & 1,5 \\
\hline \multicolumn{2}{|c|}{ Body mass, kg } & $77,7 \pm 13,0$ & $79,3 \pm 15,0$ & 2,0 \\
\hline \multicolumn{2}{|c|}{ Lean body mass, $\mathrm{kg}$} & $68,5 \pm 9,8$ & $61,0 \pm 11,4$ & 12,3 \\
\hline \multicolumn{2}{|c|}{ Fat mass, $\%$} & $11,2 \pm 3,6$ & $23,0 \pm 10,0$ & 51,3 \\
\hline \multicolumn{2}{|l|}{ Fat mass, $\mathrm{kg}$} & $9,0 \pm 4,3$ & $18,3 \pm 8,0$ & 50,8 \\
\hline \multirow{4}{*}{$\begin{array}{l}\text { Resting } \\
\text { energy } \\
\text { expenditure }\end{array}$} & $\mathrm{kcal}$ day $^{-1}$ & $2132,9 \pm 339,7$ & $1772,1 \pm 305,7^{*}$ & 20,4 \\
\hline & $\mathrm{kcal} \cdot \mathrm{kg}^{-1} \cdot$ day $^{-1}$ & $27,7 \pm 3,1$ & $22,4 \pm 3,9$ & 23,7 \\
\hline & $\mathrm{kcal} \cdot \mathrm{kg} \mathrm{LBM}{ }^{-1} \cdot$ day $^{-1}$ & $31,3 \pm 3,4$ & $29,1 \pm 5,0$ & 7,6 \\
\hline & $\begin{array}{l}\text { Adjusted, } \\
\text { kcal } \cdot \mathrm{kg} \mathrm{LBM}^{-1} \cdot \text { day }^{-1}\end{array}$ & $30,2 \pm 3,1$ & $27,7 * *$ & 9,0 \\
\hline
\end{tabular}

* significant difference $(\mathrm{p} \leq 0.05)$.

$* *$ calculated according to average data

As can be seen in Table 1, athletes and untrained men have significant differences in both body composition and metabolic levels (both in absolute and relative REE values). It is known that the magnitude of basal metabolism is significantly influenced by the body composition $[8,16]$. At the tissue-organ level, it consists of 4 components: bones, skeletal muscle, organs and adipose tissue. All these components have different metabolic activity (Table 2).

Table 2

Contribution of different organs and tissues to energy expenditure (Matthews DE, 1999)

\begin{tabular}{|l|l|l|l|l|}
\hline \multirow{2}{*}{ Organ or tissue } & \multicolumn{2}{|c|}{ Weight } & \multicolumn{2}{c|}{ Metabolic rate } \\
\cline { 2 - 5 } & $\mathrm{kg}$ & $\%$ of total & $\mathrm{kcal} \cdot \mathrm{kg}^{-1} \cdot \mathrm{day}$ & \% of total \\
\hline Kidneys & 0,3 & 0,5 & 440 & 8 \\
\hline Brain & 1,4 & 2,0 & 240 & 20 \\
\hline Liver & 1,8 & 2,6 & 200 & 21 \\
\hline Heart & 0,3 & 0,5 & 440 & 9 \\
\hline Muscle & 28,0 & 40,0 & 13 & 22 \\
\hline Adipose tissue & 15,0 & 21,4 & $4-4,5$ & 4 \\
\hline Other (skin, gut, bone, etc.) & 23,2 & 33,0 & 12 & 17 \\
\hline Total & 70,0 & 100 & & 100 \\
\hline
\end{tabular}


The most common methods of studying the body composition allow for the determination of two components: fat mass and fat-free mass, which includes all components of body weight except adipose tissue. In this distribution, the most metabolically active components (organs and skeletal muscles) are classified as LBM. Therefore, people with the same body weight, but with a higher percentage of LBM, will have higher energy expenditure at rest.

With the increase of lean body mass in athletes, higher absolute values of resting energy expenditure are observed [1,17]. This is due to an increase in skeletal muscle mass due to sports activities and possible hypertrophy of certain organs. An increase in skeletal muscle mass leads to an increase in metabolically active tissue and, consequently, to an increase in REE. In the study of athletes, we found a probable relationship between resting energy expenditure $\left(\mathrm{kcal} \cdot \mathrm{day}^{-1}\right)$ with body weight $(\mathrm{r}=0.77, \mathrm{p}<0.05)$ and lean body mass $(r=0.74, p<0,05))$. Thus, we can conclude that the differences in REE between athletes and untrained men are largely due to body composition, particularly the ratio of lean and fat body weight.

In our study, higher values of resting energy expenditure per $\mathrm{kg}$ of lean body weight were found in athletes compared to untrained men $\left(31.3 \pm 3.4 \mathrm{kcal} \cdot \mathrm{kg} \mathrm{LBM}^{-1} \cdot\right.$ day $^{-1}$ and $29.1 \pm 5.0 \mathrm{kcal} \cdot \mathrm{kg} \mathrm{LBM}^{-1} \cdot \mathrm{day}^{-1}$ respectively). This indicates a higher activity of metabolic processes in the body of athletes. Usually, an increase in LBM is accompanied by an increase in absolute resting energy expenditure $\left(\mathrm{kcal} \cdot\right.$ day $\left.^{-1}\right)$. In this case, in untrained individuals, the values of energy consumption per $\mathrm{kg}$ of LBM tend to decrease with increased lean body weight $[8,18]$. This is due to the uneven contribution to the overall metabolism of tissues with high metabolic activity and skeletal muscle. Thus, the average person's organs are about $5-6 \%$ of body weight, while consuming $58-70 \%$ of energy at rest [16]. As the lean body mass increases, mainly due to the increase in skeletal muscle mass, the share of energy expenditure associated with the metabolic activity of the organs decreases per unit of mass. However, research data in athletes indicate higher relative REE compared to general population indicators [8, 18, 12]. Thus, Midorikawa et al (2007) note that highly skilled athletes have higher energy expenditure per $\mathrm{kg}$ of LBM than untrained people with the same lean body mass [18].

Increases in relative REE per $\mathrm{kg}$ of lean body mass indicate an increase in metabolic activity of muscles, thus increasing the intensity of physiological processes, which affects the resting energy expenditure. Experts have not reached a definitive conclusion as to whether the increase in resting energy expenditure in skilled athletes is an acute response to the action of individual training sessions on the eve of measurements or there is a certain chromic effect due to regular training $[12,17]$.

It should be noted that not all researchers note higher REE in athletes compared to untrained people $[11,17]$. Also, in some cases, a significant increase in LBM in athletes is not accompanied by an increase in REE [19]. This may be due to the fact that REE may decrease after a period of intense training $[5,6,7]$. Such changes are associated with a decrease in the rate of metabolic reactions and a probable increase in catabolic processes. During intensive training, the need for energy increases significantly. When there is insufficient dietary compensation of energy expenditure, a cascade of metabolic, hormonal and nervous reactions is provoked in order to maintain homeostasis and energy conservation. Therefore, proactive monitoring of energy consumption and expenditure during intense training periods in order to individualize the training, recovery and maintenance of special performance of the athlete can help improve adaptation to intense physical activity. Determining the athletes' resting energy expenditure is promising for assessing their current state and forecasting exercise tolerance. 


\section{Conclusions}

1. Resting energy expenditure in male athletes is significantly higher $(p<0.05)$ compared to untrained men $\left(2132.9 \pm 339.7\right.$ and $1772.1 \pm 305.7 \mathrm{kcal} \cdot$ day $\left.^{-1}\right)$, which is associated with an increase in LBM and increase in its metabolic activity.

2. Among the factors influencing the REE of athletes, the greatest contribution is made by body weight $(r=0.77, p<0.05)$ and lean body mass $(r=0.74, p<0.05))$. Studies show that the REE of athletes is also influenced by the intensity of physiological processes. In particular, an decrease in REE in athletes after a period of intense training may be due to increased catabolic processes.

3. Determination of resting energy expenditure is an informative indicator of metabolic status and can be used in comprehensive monitoring of the functional status and recovery of an athlete.

\section{References (in language original)}

1. Мартинчик А. Н., Маев И. В., Янушевич О. О. Общая нутрициология. Москва: МЕДпресс-информ, 2005. $392 \mathrm{c}$.

2. Burke L., Deakin V. Clinical sports nutrition. North Ryde : McGraw-Hill, 2010. 716 p.

3. Shils M., Shike M. Modern Nutrition in Health and Disease. Philadelphia: Lippincott Williams \& Wilkins, 2006. 2069 p.

4. Thompson J. L. Resting metabolic rate and thermic effect of a meal in a low- and adequate energy intake in male endurance athletes. International Journal of Sport Nutrition. 1993. №3. P. 194-206. doi:10.1123/ijsn.3.2.194

5. New approaches to determine fatigue in elite athletes during intensified training: Resting metabolic rate and pacing profile. Plos One. 12 Vol.12, №3. doi:10.1371/journal.pone.0173807

6. Novel insights of overtraining syndrome discovered from the EROS study. BMJ Open Sport \& Exercise Medicine. 2019. Vol.5, №1 doi: 10.1136/bmjsem-2019-000542.

7. The effects of intensified training on resting metabolic rate (RMR), body composition and performance in trained cyclists. Plos One. 2018. Vol.13, №2. doi: 10.1371/journal.pone.0191644.

8. Ravussin E, Bogardus C. Relationship of genetics, age, and physical fitness to daily energy expenditure and fuel utilization. The American Journal of Clinical Nutrition. Vol 49, № 5. P. 968-975. doi:10.1093/ajen/49.5.968

9. Alméras N., Mimeault N., Serresse O., Boulay M. R., Tremblay A. Non-exercise daily energy expenditure and physical activity pattern in male endurance athletes. European Journal of Applied Physiology and Occupational Physiology. 1991. №63. P. 184-187. doi:10.1007/bf00233845

10. Taguchi M., Higuchi M., Oka, J., Yoshiga C., Ishida Y., Matsushita M. Basal Metabolic Rate in Japanese Female Endurance Athletes. The Japanese Journal of Nutrition and Dietetics. 2001. №59. P. 127-134. doi:10.5264/eiyogakuzashi.59.127

11. Koshimizu T., Matsushima Y., Yokota Y., Yanagisawa K., Nagai S., Okamura K., Komatsu Y., Kawahara T. Basal metabolic rate and body composition of elite Japanese male athletes. The Journal of Medical Investigation. 2012. №59. P. 253-260. doi:10.2152/jmi.59.253

12. Speakman J. R., Selman C. Physical activity and resting metabolic rate. Proceedings of the Nutrition Society. 2003. №62. P. 621-634. doi:10.1079/pns2003282

13. Müller M. J., Bosy-Westphal A., Later W., Haas V., Heller M. Functional body composition: insights into the regulation of energy metabolism and some clinical applications. European Journal of Clinical Nutrition. 2009. №63. P. 1045-1056. doi: 10.1038/ejen.2009.55.

14. Bouchard C., Tremblay A., Nadeau A., Després J., Thériault G., Boulay M., Lortie G., Leblanc C., Fournier G. Genetic effect in resting and exercise metabolic rates. Metabolism. 1989. P. 364-370. doi:10.1016/00260495(89)90126-1

15. Heymsfield S. B., Gallagher D., Kotler D. P., Wang Z., Allison D. B., Heshka S. Body-size dependence of resting energy expenditure can be attributed to nonenergetic homogeneity of fat-free mass. American Journal of Physiology-Endocrinology and Metabolism. 2002. №282. P. 132-138. doi:10.1152/ajpendo.2002.282.1.e132

16. Wang Z., Heshka S., Gallagher D., Boozer C. N., Kotler D. P., Heymsfield S. B. Resting energy expenditure-fat-free mass relationship: new insights provided by body composition modeling. American Journal of Physiology-Endocrinology and Metabolism. 2000. №279. P. 539-545. doi:10.1152/ajpendo.2000.279.3.e539 
17. Bullough R. C., Gillette C. A., Harris M. A., Melby C. L. Interaction of acute changes in exercise energy expenditure and energy intake on resting metabolic rate. The American Journal of Clinical Nutrition. 1995. №61. P. 473-481. doi:10.1093/ajen/61.3.473

18. Midorikawa T., Kondo M., Beekley M. D., Koizumi K., Abe T. High REE in Sumo Wrestlers Attributed to Large Organ-Tissue Mass. Medicine \& Science in Sports \& Exercise. 2007. №39. P. 688-693. doi:10.1249/mss.0b013e31802f58f6

19. Mackenzie-Shalders K. L., Byrne N. M., King N. A., Slater G. J. Are increases in skeletal muscle mass accompanied by changes to resting metabolic rate in rugby athletes over a pre-season training period? European Journal of Sport Science. 2019. №19. P. 885-892. doi:10.1080/17461391.2018.1561951

\section{References}

1. Martinchik A. N., Maev I. V., Yanushevich O. O. (2005). Obshchaya nutritsiologiya [Genereal nutrition]. Moscow, Russia: Medpress-inform (in Rus).

2. Burke, L., \& Deakin, V. (2010). Clinical sports nutrition. McGraw-Hill Book Company Australia.

3. Shils, M. E., \& Shike, M. (2006). Modern nutrition in health and disease. Philadelphia, PA: Lippincott Williams \& Wilkins.

4. Thompson, J., Manore, M. M., \& Skinner, J. S. (1993). Resting Metabolic Rate and Thermic Effect of a Meal in Low- and Adequate-Energy Intake Male Endurance Athletes. International Journal of Sport Nutrition, 3(2), 194-206. doi:10.1123/ijsn.3.2.194

5. Woods, A. L., Garvican-Lewis, L. A., Lundy, B., Rice, A. J., \& Thompson, K. G. (2017). New approaches to determine fatigue in elite athletes during intensified training: Resting metabolic rate and pacing profile. Plos One, 12(3). doi:10.1371/journal.pone. 0173807

6. Cadegiani, F. A., \& Kater, C. E. (2019). Novel insights of overtraining syndrome discovered from the EROS study. BMJ Open Sport \& Exercise Medicine, 5(1). doi:10.1136/bmjsem-2019-000542

7. Woods, A. L., Rice, A. J., Garvican-Lewis, L. A., Wallett, A. M., Lundy, B., Rogers, M. A., . . Thompson, K. G. (2018). The effects of intensified training on resting metabolic rate (RMR), body composition and performance in trained cyclists. Plos One, 13(2). doi:10.1371/journal.pone.0191644

8. Ravussin, E., \& Bogardus, C. (1989). Relationship of genetics, age, and physical fitness to daily energy expenditure and fuel utilization. The American Journal of Clinical Nutrition, 49(5), 968-975. doi:10.1093/ajen/49.5.968

9. Alméras, N., Mimeault, N., Serresse, O., Boulay, M. R., \& Tremblay, A. (1991). Non-exercise daily energy expenditure and physical activity pattern in male endurance athletes. European Journal of Applied Physiology and Occupational Physiology, 63(3-4), 184-187. doi:10.1007/bf00233845

10. Taguchi, M., Higuchi, M., Oka, J., Yoshiga, C., Ishida, Y., \& Matsushita, M. (2001). Basal Metabolic Rate in Japanese Female Endurance Athletes. The Japanese Journal of Nutrition and Dietetics, 59(3), 127-134. doi:10.5264/eiyogakuzashi.59.127

11. Koshimizu, T., Matsushima, Y., Yokota, Y., Yanagisawa, K., Nagai, S., Okamura, K., . . Kawahara, T. (2012). Basal metabolic rate and body composition of elite Japanese male athletes. The Journal of Medical Investigation, 59(3.4), 253-260. doi:10.2152/jmi.59.253

12. Speakman, J. R., \& Selman, C. (2003). Physical activity and resting metabolic rate. Proceedings of the Nutrition Society, 62(3), 621-634. doi:10.1079/pns2003282

13. Müller, M. J., Bosy-Westphal, A., Later, W., Haas, V., \& Heller, M. (2009). Functional body composition: Insights into the regulation of energy metabolism and some clinical applications. European Journal of Clinical Nutrition, 63(9), 1045-1056. doi:10.1038/ejen.2009.55

14. Bouchard, C., Tremblay, A., Nadeau, A., Després, J., Thériault, G., Boulay, M., . . Fournier, G. (1989). Genetic effect in resting and exercise metabolic rates. Metabolism, 38(4), 364-370. doi:10.1016/00260495(89)90126-1

15. Heymsfield, S. B., Gallagher, D., Kotler, D. P., Wang, Z., Allison, D. B., \& Heshka, S. (2002). Body-size dependence of resting energy expenditure can be attributed to nonenergetic homogeneity of fat-free mass. American Journal of Physiology-Endocrinology and Metabolism, 282(1), 132-138. doi:10.1152/ajpendo.2002.282.1.e132

16. Wang, Z., Heshka, S., Gallagher, D., Boozer, C. N., Kotler, D. P., \& Heymsfield, S. B. (2000). Resting energy expenditure-fat-free mass relationship: New insights provided by body composition modeling. American Journal of Physiology-Endocrinology and Metabolism, 279(3), 539-545. doi:10.1152/ajpendo.2000.279.3.e539

17. Bullough, R. C., Gillette, C. A., Harris, M. A., \& Melby, C. L. (1995). Interaction of acute changes in exercise energy expenditure and energy intake on resting metabolic rate. The American Journal of Clinical Nutrition, 61(3), 473-481. doi:10.1093/ajcn/61.3.473 
18. Midorikawa, T., Kondo, M., Beekley, M. D., Koizumi, K., \& Abe, T. (2007). High REE in Sumo Wrestlers Attributed to Large Organ-Tissue Mass. Medicine \& Science in Sports \& Exercise, 39(4), 688-693. doi:10.1249/mss.0b013e31802f58f6

19. Mackenzie-Shalders, K. L., Byrne, N. M., King, N. A., \& Slater, G. J. (2019). Are increases in skeletal muscle mass accompanied by changes to resting metabolic rate in rugby athletes over a pre-season training period? European Journal of Sport Science, 19(7), 885-892. doi:10.1080/17461391.2018.1561951

У статті представлені результати досліджень енерговитрат спокою (ЕВС) та композиційного складу тіла у кваліфікованих спортсменів та порівняння з показниками нетренованих людей. Встановлено, що спортсмени мають достовірно вищі показники енерговитрат спокою, що зумовлено більшою безжировою масою тіла.

Ключові слова: спортсмени; метаболізм; енерговитрати в стані спокою; композиційний склад тіла; безжирова маса тіла.

Одержано редакцією

Прийнято до публікації
28.08.20

05.10 .20 